\title{
Analisis Kesulitan Peserta Didik Kelas VIII dalam Menyelesaikan Soal Sistem Persamaan Linear Dua Variabel (SPLDV) di MTs Atsauri Sindangkerta
}

\author{
Ani Maryani ${ }^{1}$, Wahyu Setiawan ${ }^{2}$ \\ 1, 2 IKIP SILIWANGI, J1. Terusan Jenderal Sudirman, Cimahi Tengah, Kota Cimahi, Jawa Barat \\ animaryani00002@gmail.com
}

\begin{abstract}
This study aims to analyze the difficulties of students in solving problems on the material of the Two-Variable Linear Equation System (TVLES). The subjects of this study were 15 students of class VIII MTs Atsauri Foudation, Sindangkerta District, West Bandung Regency. This type of research is descriptive qualitative with a case study design. Data collection was obtained by interviewing and giving a test in the form of a description of the TVLES material as many as three questions which were then analyzed the difficulties faced by students. Based on the results of the study, it was concluded that students still had difficulty solving TVLES questions, as seen from the test results obtained were still not optimal. This is because students still have difficulty understanding the concept of TVLES, using methods in determining the set of TVLES completion and difficulties in understanding supporting material.
\end{abstract}

Keywords: Difficulties, a two-variable system of linear equations

\begin{abstract}
Abstrak
Penelitian ini bertujuan untuk menganalisis kesulitan peserta didik dalam menyelesaikan soal pada materi Sistem Persamaan Linear Dua Variabel (SPLDV). Subjek penelitian ini adalah 15 orang peserta didik kelas VIII MTs Atsauri Foundation Kecamatan Sindangkerta Kabupaten Bandung Barat. Jenis penelitian ini adalah deskriptif kualitatif dengan desain studi kasus. Pengambilan data diperoleh dengan memberikan tes berbentuk uraian tentang materi SPLDV sebanyak tiga soal yang kemudian dianalisis kesulitan yang dihadapi oleh peserta didik. Berdasarkan hasil penelitian disimpulkan bahwa peserta didik masih mengalami kesulitan menyelesaikan soal SPLDV, terlihat dari hasil tes yang didapatkan masih kurang maksimal. Hal itu disebabkan karena peserta didik masih mengalami kesulitan memahami konsep SPLDV, mengubah soal cerita kedalam bentuk matematika, menggunakan metode-metode dalam menentukan himpunan penyelesaian SPLDV dan kesulitan dalam memahami materi pendukung.
\end{abstract}

Kata kunci: Kesulitan, Sistem Persamaan Linear Dua Variabel

Copyright (c) 2021 Ani Maryani, Wahyu Setiawan

Corresponding author: Ani Maryani

Email Address: animaryani00002@gmail.com (Jl. Terusan Jenderal Sudirman, Cimahi, Jawa Barat, Indonesia)

Received 20 July 2021, Accepted 28 July 2021, Published 10 August 2021

\section{PENDAHULUAN}

Salah satu sektor penting dalam keberlangsungan hidup umat manusia adalah sector dunia pendidikan. Pendidikan ialah sebuah proses interaksi antara pendidik dan peserta didik baik secara formal, nonformal maupun informal (Rasnawati et al., 2019). Matematika menjadi ibu dari berbagai jenis ilmu pengetahuan memiliki peranan yang signifikan di dalam dunia pendidikan. Oleh sebab itu, matematika mempunyai tingkat urgensitas yang tinggi karena merupakan suatu landasan awal bagi terciptanya sumber daya manusia yang berpikir cerdas, kritis dan berkualitas. Matematika juga merupakan salah satu dari ilmu yang mengandalkan proses berpikir (Novtiar \& Aripin, 2017). Menurut Rajagukguk (2015) matematika adalah salah satu ilmu dasar yang penting untuk dipelajari disekolah karena pemanfaatannya yang luas bagi berbagai aspek kehidupan manusia. Ruseffendi (dalam Miftah, 2009) mengemukakan bahwa matematika merupakan ilmu keteraturan, ilmu yang terstruktur yang terorganisasikan mulai dari unsur yang tidak didefinisikan, selanjutnya ke unsuran yang didefinisikan yang dilanjutkan ke aksioma atau ponsulat dan 
terakhir memperoleh dalil. Oleh karena itu matematika menjadi mata pelajaran penting yang harus dipelajari di sekolah mulai dari tingkat dasar hingga tahap perguruan tinggi. Menurut Purnamasari \& Setiawan (2019) menjelaskan berbagai alasan perlunya sekolah mengajarkan matematika kepada siswa pada hakikatnya dikarenakan matematika memiliki peranan penting dalam terbentuknya pola pikir dan erat kaitannya dengan kehidupan manusia sehari-hari (Kulsum et al., 2019; Surya et al., 2020).

Tetapi disamping pentingnya mempelajari matematika, dalam kenyataannya terdapat permasalahan yang sampai saat ini belum terselesaikan, yaitu siswa masih menganggap bahwa matematika itu sulit untuk dipelajari (Wijaya, Ying, et al., 2020). Terbukti dengan hasil penelitian Siregar (2017) mengungkapkan sebanyak 45\% peserta didik menyatakan pembelajaran matematika itu sulit. Cahyaningsih (2018) mempertegas pernyataan tersebut bahwa matematika menjadi pelajaran yang kurang diminati oleh peserta didik. Merasa sulitnya peserta didik dalam pelajaran matematika dikarenakan banyaknya kendala atau hambatan yang dihadapi peserta didik dalam mencapai hasil belajar matematika. Menurut Abdurrahman (Syafmen, 2015) bahwa kesulitan belajar bisa diartikan juga sebagai suatu kondisi dalam proses pembelajaran yang ditandai dengan adanya kendala-kendala tertentu untuk mencapai hasil belajar. Kendalakendala tersebut dapat bersifat sosiologis, psikologis, maupun fisiologis dalam keseluruhan proses belajarnya. Sedangkan menurut Rahajeng (2012) kesulitan belajar matematika tidak selalu berarti bahwa anak tersebut tidak mampu belajar, tetapi dikarenakan anak mengalami kesulitan tertentu yang menyebabkannya tidak siap untuk belajar. Kesulitan belajar matematika pada umumnya berhubungan dengan ketidakmampuan peserta didik dalam berimajinasi, membaca, mengintegrasikan pengetahuan yang sudah diketahui sebelumnya dan pengalaman, terutama dalam memahami soal-soal yang dituangkan dalam berntuk cerita. Peserta didik terkadang kesulitan untuk mencerna suatu fenomena yang masih abstrak, sehingga sesuatu yang abstrak tersebut harus divisualisasikan atau dibuat kedalam bentuk konkret sehingga bisa dipahami dengan mudah oleh peserta didik.

Matematika terdiri dari berbagai macam cabang materi yang dipelajari dalam mata pelajaran matematika, salah satunya adalah materi aljabar. Materi tersebut harus di pelajari peserta didik pada jenjang Sekolah Menengah Pertama (SMP) yang salah satunya membahas mengenai Sistem Persamaan Linear Dua Variabel (SPLDV) (Wijaya, Ying, et al., 2020; Zulfah et al., 2020). Pokok bahasan ini erat kaitannya dengan penyelesaian masalah dalam kehidupan sehari-hari yang berbentuk soal cerita, sehingga memerlukan kemampuan peserta didik yang disebut dengan literasi matematik (Wijaya, Hidayat, et al., 2020).

Kedudukan materi Sistem Persamaan Linear Dua Variabel (SPLDV) yang tertera dalam kurikulum 2013 ialah sebagai pengetahuan awal untuk mempelajari materi berikutnya seperti program linear dan Sistem Persamaan Linear Tiga Variabel (SPLTV). Sebagaimana yang dikemukakan Sari \& Lestari (2020) menyatakan materi SPLDV ialah kelanjutan dari materi persamaan linear satu variabel dan menjadi prasyarat untuk mempelajari materi SPLTV. Namun kenyataannya masih banyak peserta didik yang mengalami kesulitan dalam menyelesaikan soal SPLDV. Masih menurut Sari dan Lestari (2020) menyatakan kesulitan yang dialami peserta didik dalam menyelesaikan soal SPLDV ialah kesulitan untuk menuliskan soal bentuk uraian kedalam simbol matematika dikarenakan peserta didik tidak menguasai 
konsep SPLDV, kesulitan dalam pengoperasian SPLDV dikarenakan peserta didik lupa pada materi yang telah dipelajari sebelumnya dan kurangnya ketelitian dalam mengerjakan soal.

Berdasarkan paparan di atas penulis tertarik untuk melaksanakan penelitian tentang kesulitan yang di alami peserta didik dalam menyelesaikan soal Sistem Persamaan Linear Dua Variabel (SPLDV). Hasil dari penelitian ini diharapkan dapat menjadi salah satu acuan dalam merancang pembelajaran yang lebih baik sehingga bisa meminimalisir kesulitan peserta didik dalam menyelesaikan soal SPLDV.

\section{METODE}

Penelitian ini menggunakan metode desktiptif kualitatif dengan menggunakan desain studi kasus. Karena tujuan dari penelitian ini untuk memperoleh gambaran apa adanya tentang kesulitan penguasaan konsep matematika peserta didik pada materi SPLDV. Menurut Sukmadinata (Cut Fitriani \& Usman, 2017), penelitian deskriptif dengan studi kasus artinya penelitian difokuskan pada satu fenomena saja yang dipilih dan ingin dipahami lebih mendalam dengan mengabaikan fenomena lain. Penelitian deskriptif bertu juan untuk mengumpulkan dan menganalisis fenomena yang ada. Penelitian ini dilakukan tanpa memberikan perlakuan, manipulasi atau pengubahan pada variable bebas tetapi menggambarkan kondisi sebenarnya. Secara singkat kerangka berpikir dalam penelitian ini sebagai berikut:

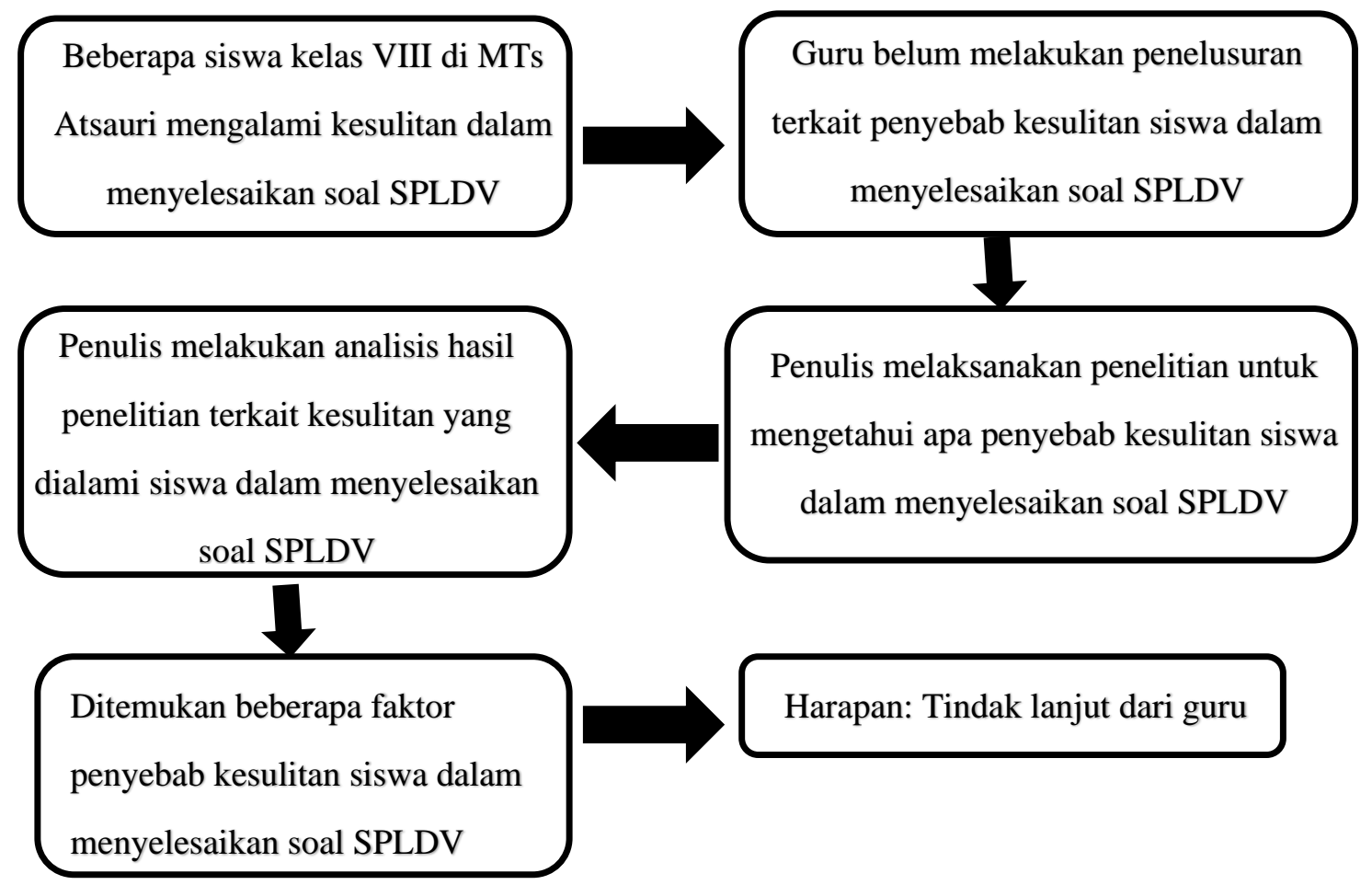

Gambar 1. Kerangka Berpikir Penelitian

Subjek pada penelitian ini adalah peserta didik kelas VIII MTs Atsauri Foudation Kecamatan Sindangkerta Kabupaten Bandung Barat yang berjumlah 15 peseta didik. Teknik pengumpulan data menggunakan tes berbentuk soal uraian tentang materi Sistem Persamaan Linear Dua Variabel (SPLDV) sebanyak tiga butir soal dan analisis peserta didik. Adapun teknik pengolahan data dilakukan dengan cara 
menganalisis hasil jawaban siswa berdasarkan faktor-faktor yang ditemui tentang penyebab kesulitan siswa dalam mengerjakan soal, kemudian dihitung menggunakan cara persentase.

Tabel 1. Soal Tes

\begin{tabular}{|c|l|}
\hline No & \multicolumn{1}{|c|}{ Soal } \\
\hline 1 & Harga 2 pasang sepatu dan 3 pasang sandal adalah Rp 270.000, sedangkan harga 3 pasang \\
& sepatu dan 4 pasang sandal adalah Rp 390.000. Tentukanlah berapa harga 4 pasang sepatu \\
& dan 2 pasang sandal!
\end{tabular}

\section{HASIL DAN DISKUSI}

Berdasarkan hasil penelitian, pada umumnya peserta didik tidak menyenangi pelajaran matematika karena dianggap membingungkan. Latar belakang pendidikan orang tua tidak mendukung dalam membimbing ketika belajar di rumah. Selama pembelajaran, peserta didik terlihat pasif dan bercanda, mengobrol serta bermain. Peserta didik tidak dapat mengkomunikasikan soal cerita ke dalam kalimat matematika. Peserta didik ada yang belum memahami konsep SPLDV dan metode-metode yang digunakan dalam menyelesaikan soal SPLDV.

Berdasarkan hasil penelitian terhadap 15 peserta didik di MTs Atsauri Foundation Kecamatan Sindangkerta kelas VIII, analisis dilakukan pada jawaban yang berisi langkah kerja dalam penyelesaian soal yang diberikan dapat dilihat pada tabel persentase berikut ini.

Tabel 2. Persentase Kemampuan Peserta Didik

\begin{tabular}{|c|l|c|c|}
\hline No. & \multicolumn{1}{|c|}{ Soal } & Mampu & Tidak Mampu \\
\hline 1 & $\begin{array}{l}|c| \\
\text { Indikator: Menentukan penyelesaian masalah dalam kehidupan nyata yang berkaitan } \\
\text { dengan SPLDV }\end{array}$ & $5(33,33 \%)$ & $10(66,67 \%)$ \\
\cline { 2 - 4 } & Memahami konsep SPLDV & $4(26,67 \%)$ & $11(73,33 \%)$ \\
\cline { 2 - 4 } & $\begin{array}{l}\text { Memahami metode-metode dalam menentukan } \\
\text { penyelesaian SPLDV }\end{array}$ & $30 \%$ & $70 \%$ \\
\hline \multirow{2}{*}{2} & \multicolumn{1}{|c|}{ Rata-rata } & $\begin{array}{l}\text { Indikator: Menentukan penyelesaian dari SPLDV dengan menggunakan metode } \\
\text { substitusi }\end{array}$ \\
\cline { 2 - 4 } & $\begin{array}{l}\text { Penguasaan materi pendukung (operasi hitung } \\
\text { bentuk aljabar) }\end{array}$ & $6(40 \%)$ & $9(60 \%)$ \\
\cline { 2 - 4 } & Memahami konsep SPLDV & $6(40 \%)$ & $10(60 \%)$ \\
\cline { 2 - 3 } & $\begin{array}{l}\text { Memahami metode substitusi dalam menentukan } \\
\text { penyelesaian SPLDV }\end{array}$ & $5(33,33 \%)$ \\
\hline & \multicolumn{3}{|c|}{ Rata-rata } \\
\hline & Indikator: Menentukan himpunan penyelesaian dengan menggunakan grafik \\
\hline
\end{tabular}


Analisis Kesulitan Peserta Didik Kelas VIII dalam Menyelesaikan Soal Sistem Persamaan Linear Dua Variabel (SPLDV) di MTs Atsauri Sindangkerta, Ani Maryani, Wahyu Setiawan

\begin{tabular}{|c|l|c|c|}
\hline No. & \multicolumn{1}{|c|}{ Soal } & Mampu & Tidak Mampu \\
\hline 3 & $\begin{array}{l}\text { Memahami metode grafik dalam menentukan } \\
\text { himpunan penyelesaian SPLDV }\end{array}$ & $3(20 \%)$ & $12(80 \%)$ \\
\cline { 2 - 4 } & $\begin{array}{l}\text { Penguasaan materi pendukung (operasi hitung } \\
\text { bentuk aljabar) }\end{array}$ & $5(33,33 \%)$ & $10(66,67 \%)$ \\
\hline & \multicolumn{1}{|c|}{ Rata-rata } & $26,67 \%$ & $73,33 \%$ \\
\hline
\end{tabular}

Tabel di atas menunjukkan bahwa kemampuan peserta didik dalam menyelesaikan soal pada materi segiempat masih kurang maksimal. Berdasarkan analisis terhadap kesalahan- kesalahan jawaban peserta didik diketahui terdapat empat faktor penyebab kesulitan peserta didik mengerjakan soal yaitu: (1) kurang memahami konsep SPLDV, dibuktikan dengan diperoleh rata-rata sebanyak 66,67\%; (2) kurang memahami metode substitusi dalam menentukan penyelesaian SPLDV, dibuktikan dengan diperoleh rata-rata sebanyak 66,67\%; (3) kurang memahami metode grafik dalam menentukan penyelesaian SPLDV, dibuktikan dengan diperoleh rata-rata sebanyak 80\%; dan, (4) kurangnya penguasaan materi pendukung dari SPLDV, seperti operasi hitung bentuk aljabar, dibuktikan dengan diperoleh rata-rata sebanyak 63,33\%. Keempat faktor tersebut memiliki rata-rata diatas 50\%, hal ini menunjukan bahwa keempat faktor tersebut menjadi kesulitan utama yang dialami siswa dalam menyelesaikan soal SPLDV. Senada dengan hasil penelitian Maspupah dan Purnama (2020) bahwa kesulitan peserta didik dalam menyelesaikan soal SPLDV adalah peserta didik kesulitan dalam mengubah soal ke dalam model matematika, sulit memahami informasi yang disajikan, siswa tidak dapat menentukan penyelesaian soal menggunakan metode-metode yang bisa digunakan dalam menyelesaikan SPLDV, siswa kesulitan menerapkan konsep SPLDV dan kurangnya kemampuan peserta didik dalam mengusai materi pendukung SPLDV berupa operasi hitung aljabar. Berikut ini ditampilkan contoh dari jawaban peserta didik dalam mengerjakan soal.

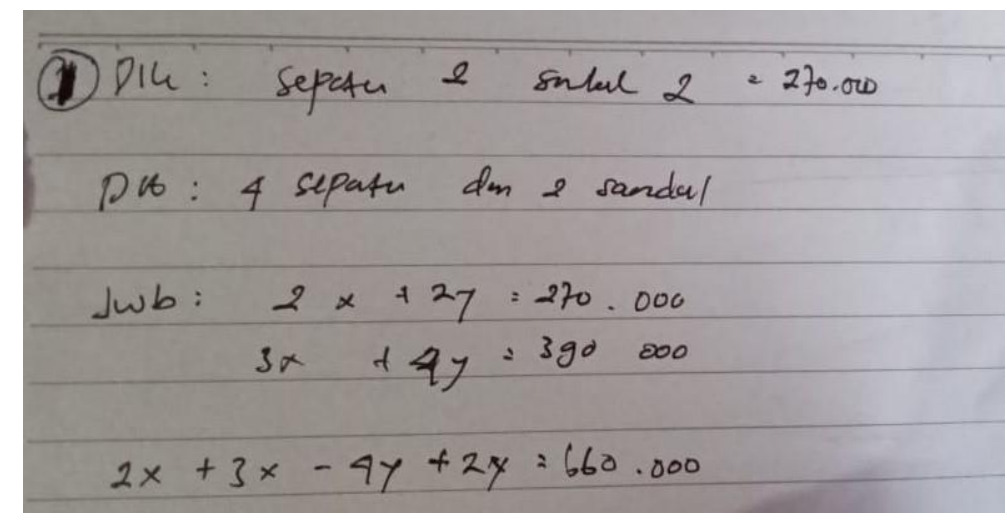

Gambar 1. Contoh Jawaban Soal No 1

Pada Gambar 1 terlihat peserta didik berusaha untuk menyelesaikan soal akan tetapi peserta didik tidak mengerti konsep dari SPLDV. Peserta didik tidak memahami informasi yang disajikan, terlihat dari apa yang dituliskan pada bagian diketahui. Peserta didik hanya menuliskan satu informasi saja dan itu pun masih keliru. Dari proses penyelesaian juga nampak bahwa peserta didik kebingungan dalam menentukan himpunan penyelesaian SPLDV baik itu dengan metode eliminasi, substitusi, grafik dan campuran. 
Pada soal nomor 1 peserta didik belum memahami konsep SPLDV dan belum memahami metodemetode dalam menentukan himpunan penyelesaian SPLDV. Hal ini sejalan dengan penelitian Maspupah \& Purnama (2020) tentang analisis kesulitan siswa dalam menyelesesaikan soal cerita SPLDV ditinjau dari perbedaan gender. Selain itu berdasarkan analisis yang dilakukan siswa cenderung melakukan langkah penyelesaian secara asal-asalan. Hal tersebut senada dengan hasil penelitian yang dilakukan Selvia, Rochmatin, \& Zanthy (2019) tentang analisis kemampuan pemecahan masalah dan kemampuan penalaran matematik siswa SMP pada materi SPLDV bahwa peserta didik tidak paham dalam merubah soal kedalam model matematika atau membuatnya dalam bentuk aljabar sehingga peserta didik menjawab soal hanya asal-asalan. Kesulitan dalam menyelesaikan soal cerita tidak hanya di alami oleh peserta didik yang memiliki kemampuan matematika rendah, tapi juga di alami oleh peserta didik yang memiliki kemampuan matematika sedang dan tinggi. Hal tersebut sejalan dengan hasil penelitian Dwidarti, Mampouw \& Setyadi (2019) mengatakan bahwa tidak hanya peserta didik yang mempunyai kemampuan matematika rendah yang mengalami kesulitan, akan tetapi peserta didik yang mempunyai kemampuan matematika tinggi dan kemampuan matematika sedang juga masih mengalami kesulitan dalam menyelesaikan soal cerita matematika. Selain itu, kurangnya kemampuan pemecahan masalah siswa juga mempengaruhi terhadap penyelesaian permasalahan yang diberikan.

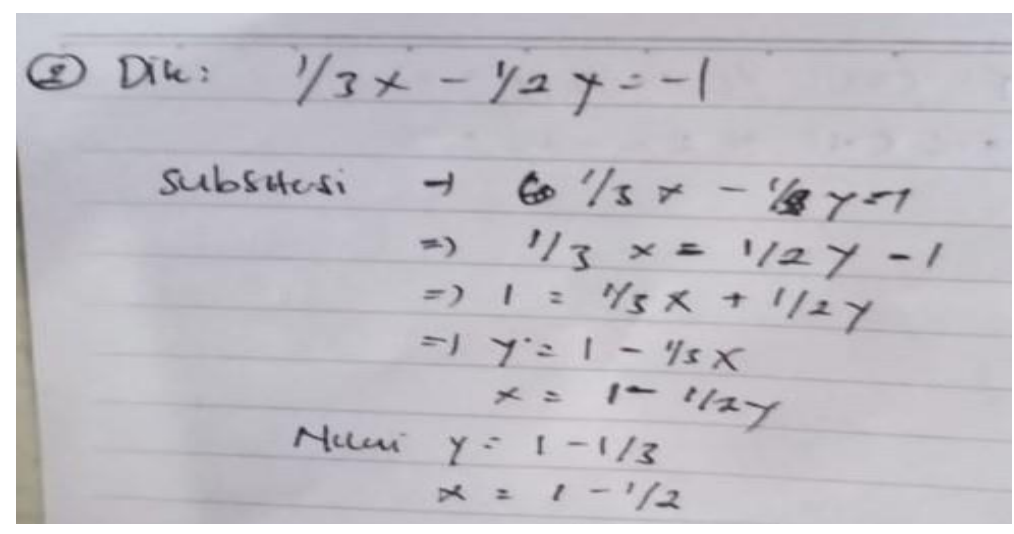

Gambar 2. Contoh jawaban soal no 2.

Pada Gambar 2 terlihat peserta didik tidak hanya menuliskan satu persamaan linear pada bagian diketahui, hal ini memnunjukkan bahwa peserta didik tidak memahami konsep SPLDV yang salah satunya adalah bahwa SPLDV itu adalah sistem/ kesatuan dari Persamaan Linear Dua Variabel (PLDV) yang sejenis. Pada proses penyelesaian peserta didik masih kesulitan dalam melakukan operasi hitung aljabar dan kesulitan menggunakan metode substitusi dalam menentukan himpuan penyelesain dari SPLDV yang diketahu pada soal. Hasil akhir peserta didik menuliskan penyelesaian SPLDV dengan asal- asalan tanpa proses atau langkah yang jelas.

Pada soal nomor 2, peserta didik belum memahami metode substitusi dalam menentukan himpunan penyelesaian SPLDV dan juga belum memahami operasi bentuk aljabar sehingga peserta didik kesulitan dalam melakukan operasi hitung aljabar. Hal ini sejalan dengan penelitian yang dilakukan Puspitasari, Yusmin \& Nursangaji (2015) mengemukakan bahwa siswa masih kesulitan dalam merencanakan penyelesaian dan melakukan operasi hitung bentuk aljabar. 


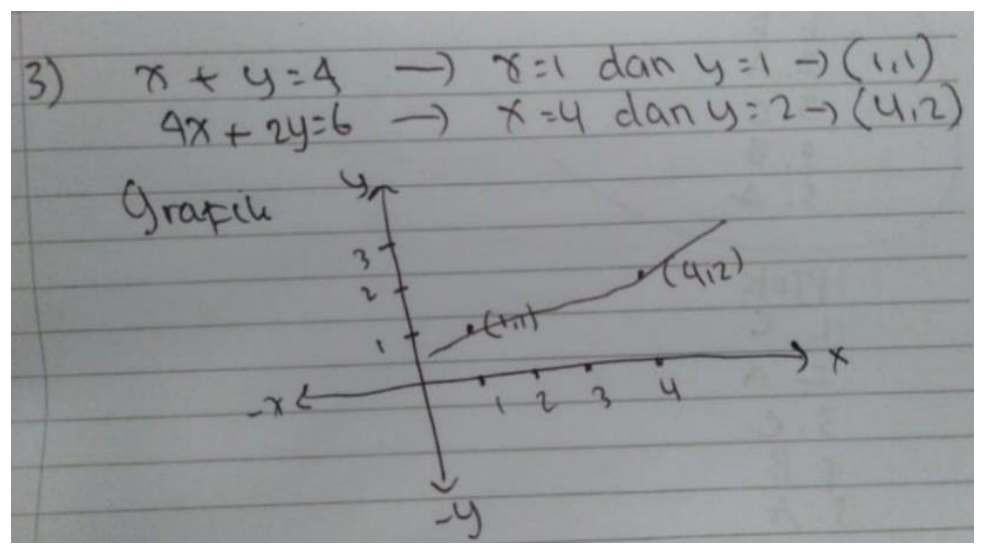

Gambar 3. Contoh jawaban soal no. 3

Pada Gambar 3 terlihat peserta didik memahami maksud dari apa yang ditanyakan pada soal nomor 3 yaitu mencari penyelesaian dengan menggunakan grafik. Akan tetapi proses penyelesaiannya masih keliru. Langkah awal dalam mencari titik untuk menggambar garis dari masing masing PLDV masih keliru, sehingga garis yang ada pada bidang cartesius hanya berupa satu garis lurus. Dari hasil akhir maka siswa tidak dapat menentukan himpunan penyelesaian dari SPLDV yang ada pada soal.

Pada soal nomor 3 peserta didik peserta didik memahami maksud dari apa yang ditanyakan yaitu mencari penyelesaian dengan menggunakan metode grafik. Akan tetapi proses penyelesaiannya masih keliru. Dari setiap SPLDV peserta didik hanya mencari satu titik untuk di gambarkan pada bidang cartesius, sehingga pada bidang cartesius hanya ada satu garis lurus. Dari proses tersebut, dapat di amati bahwa peserta didik tidak dapat menentukan himpunan penyelesaian dari SPLDV yang diketahui. Ini menunjukkan bahwa peserta didik masih kesulitan dalam menentukan himpunan penyelesaian SPLDV menggunakan metode grafik. Hal ini Senada dengan penelitian yang dilakukan oleh Agustini dan Pujiastuti (2020) mengemukakan bahwa siswa masih kesulitan dalam menggunakan metode grafik untuk mencari penyelesaian SPLDV. Serta dikuatkan oleh Rahmawati, Bernard, \& Akbar (2019) yang menemukan bahwa siswa dalam penelitiannya kesulitan menyatakan peristiwa sehari-hari dalam bahasa matematika serta kesulitan untuk menghubungkan grafik dengan ide matematika.

Berdasarkan analisis hasil data di atas masih terdapat peserta didik yang belum memahami materi pendukung SPLDV. Hasibuan (2015) mengemukakan bahwa kesalahan yang terjadi pada saat peserta didik menyelesaikan soal SPLDV tidak terlepas dari materi sebelumnya yang belum dikuasainya dengan baik, seperti operasi hitung aljabar. Lineaus (Hutauruk, 2018) menurut hasil penelitiannya pada siswa kelas IX SMA, mengemukakan bahwa saat pembelajaran di kelas sedang berlangsung, seringkali ditemukan beberapa pesera didik mengalami kesulitan dalam memahami pelajaran, termasuk pada pelajaran SPLDV khususnya jika materi tersebut disajikan dalam bentuk soal cerita. Peserta didik merasakan kesulitan dalam memahami masalah yang dibuat dalam bentuk soal cerita dan kesulitan menafsirkannya ke dalam model matematika, padahal dasar pembelajaran SPLDV itu sendiri telah dipelajari sejak duduk di kelas VII. 


\section{KESIMPULAN}

Hasil analisis dari penelitian ini menunjukan bahwa masih banyak peserta didik yang mengalami kesulitan dalam menyelesaikan soal SPLDV, terlihat dari hasil tes yang didapatkan masih kurang maksimal. Hal ini disebabkan karena peserta didik masih mengalami kesulitan memahami konsep SPLDV, mengubah soal cerita kedalam bentuk matematika, menggunakan metode-metode dalam menentukan himpunan penyelesaian SPLDV dan masih kesulitan dalam memahami materi pendukung SPLDV.

\section{UCAPAN TERIMA KASIH}

Ucapkan terimakasih kepada Ikip Siliwangi selaku tempat peneliti menempuh pendidikan, kepada Bapak Wahyu Setiawan selaku dosen pembimbing, kepada sekolah MTs Atsauri Foundation Kecamatan Sindangkerta yang telah memberikan kesempatan melakukan penelitian kepada peneliti.

\section{REFERENSI}

Agustini, D., \& Pujiastuti, H. (2020). Analisis Kesulitan Siswa Berdasarkan Kemampuan Pemahaman Matematis dalam Menyelesaikan Soal Cerita Pada Materi SPLDV. Media Pendidikan Matematika, $8(1), 18-27$.

Cahyaningsih, U. (2018). Penerapan Model Pembelajaran Kooperatif Tipe TAI(Team Assisted Individualization) Untuk Meningkatkan Hasil Belajar Siswa Pada Mata Pelajaran Matematika. Jurnal Cakrawala Pendas, 4(1), 1-14.

Cut Fitriani, M. A. R., \& Usman, N. (2017). Kompetensi profesional guru dalam pengelolaan pembelajaran di MTs Muhammadiyah Banda Aceh. Jurnal Administrasi Pendidikan: Program Pascasarjana Unsyiah, 5(2).

Dwidarti, U., Mampouw, H. L., \& Setyadi, D. (2019). Analisis Kesulitan Siswa dalam Menyelesaikan Soal Cerita Pada Materi Himpunan. Jurnal Cendekia: Jurnal Pendidikan Matematika, 3(2), 315-322.

Hasibuan, I. (2015). Hasil Belajar Siswa pada Materi Bentuk Aljabar di Kelas VII SMP Negeri 1 Banda Aceh Tahun Pelajaran 2013/2014. Jurnal Peluang, 4(1).

Hutauruk, L. (2018). Kemampuan Penalaran Matematika Siswa Pada Materi SPLDV dengan Menggunakan Budaya Khas Palembang yang Berbasiskan Taksonomi SOLO Superitem Siswa Kelas IX. Prosiding Seminar Nasional Program Pascasarjana Universitas PGRI Palembang, 5(5).

Kulsum, S. I., Hidayat, W., Wijaya, T. T., \& Kumala, J. (2019). Analysis on high school students' mathematical creative thinking skills on the topic of sets. Jurnal Cendekia: Jurnal Pendidikan Matematika, 03(02), 431-436.

Maspupah, A., \& Purnama, A. (2020). Analisis Kesulitan Siswa MTs Kelas VIII Dalam Menyelesaikan Soal Cerita Sistem Persamaan Linear Dua Variabel (SPLDV) Ditinjau Dari Perbedaan Gender. Jurnal Cendekia: Jurnal Pendidikan Matematika, 4(1), 237-246.

Miftah, M. (2009). Keefektifan model pembelajaran langsung dan pembelajaran kooperatif pada materi pokok himpunan kelas VII ditinjau dari kemampuan verbal siswa. UNS (Sebelas Maret University).

Novtiar, C., \& Aripin, U. (2017). Meningkatkan kemampuan berpikir kritis matematis dan kepercayaan diri siswa SMP melalui pendekatan open ended. Prisma, 6(2), 119-131.

Purnamasari, I., \& Setiawan, W. (2019). Analisis Kemampuan Pemecahan Masalah Matematis Siswa SMP 
pada Materi SPLDV Ditinjau dari Kemampuan Awal Matematika (KAM). Journal of Medives : Journal of Mathematics Education IKIP Veteran Semarang, 3(2), 207-215.

Puspitasari, E., Yusmin, E., \& Nursangaji, A. (2015). Analisis kesulitan siswa menyelesaikan soal cerita materi sistem persamaan linear dua variabel di smp. Tanjungpura University.

Rahajeng, S. P. (2012). Kesulitan Belajar Matematika. Krida Rakyat, 2(2).

Rahmawati, N. S., Bernard, M., \& Akbar, P. (2019). Analisis Kemampuan Komunikasi Matematik Siswa Smk Pada Materi Sistem Persamaan Linier Dua Variabel (SPLDV). Journal on Education, 1(2), 344 352.

Rajagukguk, D. (2015). Penerapan Pembelajaran Berbasis Masalah Untuk Meningkatkan Kemampuan Berpikir Kritis Matematika Siswa SMP N 35 Medan Kelas VII Pada Materi Himpunan Tahun Ajaran 2014/2015. Doctoral dissertation,UNIMED.

Rasnawati, A., Rahmawati, W., Akbar, P., \& Putra, H. D. (2019). Analisis Kemampuan Berpikir Kreatif Matematis Siswa SMK Pada Materi Sistem Persamaan Linear Dua Variabel (SPLDV) di Kota Cimahi. Jurnal Cendekia: Jurnal Pendidikan Matematika, 3(1), 164-177.

Sari, P. P., \& Lestari, D. A. (2020). Analisis Kesulitan Siswa SMP dalam Menyelesaikan Soal Cerita Pada Materi Sistem Persamaan Linear Dua Variabel. Jurnal Cendekia: Jurnal Pendidikan Matematika, 4(1), 286-293.

Selvia, S., Rochmatin, T., \& Zanthy, L. S. (2019). Analisis Kemampuan Pemecahan Masalah dan Kemampuan Penalaran Matematik Siswa SMP Pada Materi SPLDV. JPMI (Jurnal Pembelajaran Matematika Inovatif), 2(5), 261-270.

Siregar, N. R. (2017). Persepsi Siswa pada pelajaran matematika: studi pendahuluan pada siswa yang menyenangi game. Prosiding Temu Ilmiah Nasional X Ikatan Psikologi Perkembangan Indonesia, 1 .

Surya, Y. F., Zulfah, Astuti, Marta, R., \& Wijaya, T. T. (2020). The Development of Open-Ended Math Questions on Grade v Students of Elementary School. Journal of Physics: Conference Series, 1613(1).

Syafmen, W. (2015). Identifikasi Kesalahan Siswa dalam Menyelesaikan Soal Matematika di SMA (Studi Kasus SMA N. 11 Kota Jambi). Kreatif, 17(3).

Wijaya, T. T., Hidayat, W., \& Zhou, Y. (2020). Development of Interactive Learning Video on Linear Program. Universal Journal of Educational Research, 8(12A), 7530-7538.

Wijaya, T. T., Ying, Z., Chotimah, S., Bernard, M., Zulfah, \& Astuti. (2020). Hawgent dynamic mathematic software as mathematics learning media for teaching quadratic functions. Journal of Physics: Conference Series, 1592(1), 1-.

Zulfah, Astuti, Surya, Y. F., Marta, R., \& Wijaya, T. T. (2020). Measurement of mathematics problems solving ability using problem based mathematics question. Journal of Physics: Conference Series, 1613(1). 